\title{
Glucose homeostasis in acromegaly: pathogenesis and effects of treatment
}

\author{
Roberto Baldelli1 \\ Renata S. Auriemma² \\ Laura Rizza ${ }^{1}$ \\ Francesca Rota ${ }^{1}$ \\ Valerio Adinolfi ${ }^{1}$ \\ Antonella Paoloni ${ }^{1}$ \\ Paola Di Giacinto ${ }^{1}$ \\ Agnese Barnabei ${ }^{1}$ \\ Marialuisa Appetecchia ${ }^{1}$ \\ Maurizio Gasperi² \\ 1 Endocrinology Unit, "Regina Elena" National Cancer \\ Institute, Rome, Italy \\ 2 Department of Medicine and Health Sciences, Chair \\ of Endocrinology, University of Molise, Campobas- \\ so, Italy
}

Address for correspondence:

Roberto Baldelli

Endocrinology Unit, "Regina Elena" National Cancer Institute

Via Elio Chianesi, 53

00144 Rome, Italy

E-mail: baldelli@ifo.it

\section{Summary}

Acromegaly is a chronic debilitating disorder resulting from excessive secretion of growth hormone (GH) and consequent increase in insulin-like growth factor I (IGF-I), usually caused by a pituitary somatotroph adenoma. Effective treatment aims to ameliorate symptoms and signs of the disease and to lower mortality rate. In particular, high morbidity and mortality are partly related to the presence of insulin resistance due to the action of $\mathrm{GH}$ on liver, muscle and adipose tissue. Insulin resistance and/or reduced insulin sensitivity physiologically result in hypersecretion of insulin from the pancreas. This compensatory state of hyperinsulinemia is felt to be a first and more important marker for this condition. Adequate control of $\mathrm{GH}$ excess by surgery or pharmacotherapy is associated with decreased insulin resistance, resulting in reduced plasma insulin and glucose levels or improved glucose tolerance. Despite divergent effects of both somatostatin and somatostatin analogs on GH, insulin and glucagon secretion, and glucose absorption, treatment with the somatostatin analogs octreotide and lanreotide has only li- mited effects on glucose metabolism. However, glucose sensitivity has been formally examined using a hyperinsulinemic euglycemic clamp only in a minority of studies. Treatment with the GH-receptor antagonist pegvisomant improves insulin sensitivity, thus decreasing circulating fasting insulin and glucose levels. Assessment of insulin secretion and glucose levels in acromegalic patients during administration of the above compounds is thus mandatory.

KEY WORDS: acromegaly, insulin-resistance, glucose homeostasis, pegvisomant, somatostatin analog, octreotide, lanreotide.

\section{Introduction}

Acromegaly is a rare but severe endocrine disease resulting from the increased release of growth hormone $(\mathrm{GH})$ and, consequentially, insulin-like growth factor I (IGF-I) usually induced by a pituitary adenoma. This slowly developing syndrome occurs with the same frequency in men and women at any age and is characterized by an increased mortality because of cardiovascular, respiratory, metabolic and oncologic complications $(1,2)$.

The therapeutic goal in acromegaly is to reduce morbidity and mortality by removing tumor mass and restoring $\mathrm{GH}$ and IGF-I values to normal range for age and sex. High morbidity and mortality are reported associated to insulin resistance due to the action of $\mathrm{GH}$ on liver, muscle and adipose tissue (3-5).

Current available treatments for acromegaly include neurosurgery, radiotherapy and medical therapy with dopamine-agonists, somatostatin analogues and the GH-receptor antagonist. In experienced hands, surgery is able to induce the definitive cure from acromegaly, according to the international criteria of cure (6), in approximately $60 \%$ of patients (7). However, in patients with large invasive tumors, representing the vast majority of cases, surgery fails to achieve the complete tumor removal and surgical effectiveness is lower (8).

Radiotherapy, both conventional external-beam or stereotactic radiosurgery with the use of gamma-knife, is indicated for patients with recurrence or persistence of disease activity after unsuccessful surgery and resistant or intolerant to medical treatment. However, limitations of radiotherapy include the very slow attenuation of GH and IGF-I levels, requiring more than 10 years to achieve the maximum hormonal control (9), 
and sometimes the secondary damage of near cerebral tissue or hypopituitarism $(10,11)$.

Dopamine-agonists, such as bromocriptine and cabergoline, are only partly effective (12). Particularly, a recent meta-analysis (13) showed that cabergoline is effective in inducing IGF-I normalization in $52 \%$ of patients with mild hormonal excess, with a poor effectiveness in those with aggressive disease. Somatostatin agonists inhibit the secretion of growth hormone, but GH and IGF-I normalization is achieved in approximately $70 \%$ of patients (14).

Acromegaly is also associated with alterations of lipid metabolism, with the incidence of hypertriglyceridemia being three times higher than normal population (15). The reduction of $\mathrm{GH}$ to "safe" levels $(<2.5 \mu \mathrm{g} / \mathrm{L})$ has been reported to reduce mortality rate $(16,17)$; therefore, the aim of all treatments is to induce disease control by suppressing GH/IGF-I hypersecretion to normal levels and to prevent complications.

This review aims at focusing on insulin resistance, a known cause of metabolic complications commonly associated to acromegaly, and particularly on its pathogenesis and the role of the different therapeutic approaches.

\section{Epidemiology}

It is known that growth hormone counteracts insulin action on peripheral tissues causing insulin resistance (18). Some studies have reported on a direct correlation between circulating $\mathrm{GH}$ plasma levels and the degree of glucose intolerance (19). Noteworthy, the development of glucose intolerance has been related to family history of diabetes and to the presence of hypertension (20). Although limited data are available regarding the role of insulin action in acromegalic patients, the observation of hyperinsulinemia and/or impaired glucose tolerance in acromegaly suggests that chronic hypersecretion of $\mathrm{GH}$ is associated with insulin resistance $(4,21-27)$. The prevalence of overt diabetes mellitus in acromegaly largely differs among studies, likely due to different patient series and ethnicity, higher age and longer disease duration, family history of diabetes, concomitant presence of arterial hypertension and hormonal levels. The prevalence of impaired glucose tolerance ranged from 16 to $46 \%$ among studies (28-30), whereas diabetes mellitus occurs in about $10-25 \%$ of acromegalic patients and it has been associated with increased mortality (2). Furthermore, in acromegaly dyslipidemia is frequently reported; particularly hypertriglyceridemia occurs in 19 to $44 \%$ of patients and a positive correlation between the serum insulin response to glucose load and increased serum triglycerides concentrations has been described (15). The increased cardiovascular morbidity and mortality are, at least partly, consequent upon the presence of insulin resistance and dyslipidemia. Moreover, in hyperinsulinemic patients blood pressure is reportedly increased, and hyperinsulinemia-induced sodium reabsorption may contribute to the increase in blood pressure in acromegalic patients (31). In an open transversal study, 130 consecutive treatmentnaive acromegalic patients were evaluated for glucose metabolism and blood pressure (20), showing glucose tolerance abnormalities and hypertension respectively in $54 \%$ and $35.4 \%$ of cases. Particularly normotensive patients with glucose tolerance alterations had an increased prevalence of impaired diastolic (40\%) and systolic (32\%) dysfunction (20).

\section{Pathogenesis}

Insulin resistance and/or reduced insulin sensitivity physiologically result in the pancreatic hypersecretion of insulin. This compensatory state of hyperinsulinemia is felt to be a first and more important marker for this condition. Insulin resistance is characterized by a reduced response to a given amount of insulin (32) and occurs in several diseases, including diabetes mellitus $(32,33)$. It has been demonstrated that after oral glucose tolerance test (OGTT) acromegalic patients with either normal or impaired glucose tolerance have reduced peripheral tissue glucose uptake, likely due to the insulin resistance in extra-hepatic tissue $(3$, $34,35)$. The underlying pathophysiological mechanisms are yet to be clarified, but a possible direct action of $\mathrm{GH}$ excess at receptor level has been proposed. $\mathrm{GH}$ hypersecretion appears to be associated with downregulation of insulin receptors (IR), and decreased IR binding affinity has been found in liver and skeletal muscle of transgenic mice for $\mathrm{GH}$ (36-38). In acromegalic patients, changes in IR binding affinity, as well as a decreased receptor expression and an increase in the affinity of the unoccupied or empty receptor are reported (35). These changes have been correlated to each other, as well as to the severity of the increase in plasma insulin and GH levels. In experimental conditions of prolonged exposure to chronic $\mathrm{GH}$ excess, changes in IR auto-phosphorilation or kinase activity have been found in rats (39-41). On the other hand, a post-binding alteration in insulin action in hepatic and extra hepatic tissues has also been proposed $(4,35)$. The decrease in maximally stimulated glucose utilization and the lack of change in monocyte and erythrocyte insulin binding suggest an impairment in post-binding function (4). Several post-receptor events are affected when cultured cells are exposed to $\mathrm{GH}$, suggesting that $\mathrm{GH}$ and insulin signalling may converge at post-receptorial levels (42-44). GH has also been shown to promote tyrosine phosphorylation of IRS-1 and IRS-2 and their association with PI-3 kinase in different $\mathrm{GH}$ responsive tissues (45-48). Another mechanism by which $\mathrm{GH}$ exerts insulin resistance is by the induction of some cellular proteins, such as SOCS-1 and SOCS-6, that are able to inhibit IR signalling (49). A role of pancreatic $\beta$-cell dysfunction in the pathogenesis of glucose intolerance in acromegaly was also postulated: by comparing plasma pro-insulin, immunoreactive insulin, C-peptide and blood glucose concentrations during oral glucose load in normotolerant acromegalic patients, it has been shown that acromegalics had higher fasting insulin, pro-insulin and C-peptide levels than controls, thus suggesting ei- 
ther that hyperproinsulinemia contributes to hyperinsulinemia, and that prolonged and excessive $\mathrm{GH}$ secretion may affect pancreatic beta-cell function (35). In acromegaly, glucose metabolism abnormalities progressively occur: in the early stage patients show hyperinsulinism with normal or borderline glucose tolerance. In the middle phase, a delayed insulin peak after glucose load associated to normal or slightly impaired glucose tolerance is reported. The third and last stage is characterized by maximal pancreatic response in fasting conditions with no further rise in insulin concentrations after glucose injection (35).

The incidence of hypercholesterolemia is similar to that of the general population, and different independent studies reported plasma cholesterol to be increased (50), normal (51) or decreased (15) in patients with acromegaly. Furthermore, an increased plasma concentration of lipoprotein (a), small dense LDL and remnant-like lipoprotein particles (RLP) has been reported (51-53). The incidence of type IV hypertriglyceridemia is three times higher than in normal population (15). Lecithin/cholesterol acyl transferase (LCAT), phospholipids transfer protein (PLTP) and cholesteryl ester transfer protein (CETP) are proteins involved in the intravascular metabolism of lipoprotein. Plasma CETP, LCAT and PLTP activity has been found decreased in acromegalic patients (54), possibly contributing to increased cardiovascular risk in these patients due to impaired reverse cholesterol transport.

In summary, in acromegaly it is not possible to identify a unique sequence of events leading to insulin resistance. The primary defect is clearly the high levels of $\mathrm{GH}$; secondly, the plasma $\mathrm{GH}$ levels could directly act in increasing basal insulin concentrations which in turn could cause the decrease in receptor concentration and the alteration in the post-receptorial mechanisms.

\section{Effects of GH/IGF-I Suppression on insulin resistance}

Biochemical control of acromegaly by normalization of either GH or IGF-I levels predicts improvement in glucose homeostasis (55). Both surgery and medical treatment resulting in biochemical cure of acromegaly have been shown to normalize fasting glucose and insulin values (55).

\section{Surgery}

Glucose tolerance abnormalities dramatically improves when normalization of circulating $\mathrm{GH}$ levels is achieved by successful surgical or pharmacological therapy. Impaired glucose tolerance (IGT) and diabetes mellitus are potentially cured if surgical tumor resection is complete and plasma GH levels are normalized, which occurs in approximately $70 \%$ of acromegalic patients, whereas in $30 \%$ of cases impaired glucose tolerance could persist (56). Increased insulin secretion may still occur after glucose adminis- tration in some patients despite the normal glucose metabolism and fasting insulin levels (57).

\section{Radiotherapy}

A few studies have investigated the effects of radiation therapy on glucose metabolism in acromegaly and limited data are nowadays available. However, radiotherapy treatment has reportedly positive effects on glucose metabolism: the reduction in plasma $\mathrm{GH}$ levels after radiotherapy correlate with the improvement of glucose tolerance (58).

\section{Pharmacological therapy}

Somatostatin analogs (SA) significantly improve GH/IGF-I control, in particular in those patients not completely cured by surgery (59). The effectiveness of medical therapy either with SA or dopamine agonists in improving glucose metabolism is controversial. Octreotide is a SA which has been shown to be effective in the treatment of acromegaly. It has been reported that octreotide has beneficial effects on carbohydrate metabolism. Ho et al. evaluated the effects of this SA by performing a glucose tolerance test and an euglycemic hyperinsulinemic clamp (60) showing the normalization of glucose tolerance in 4 out of 5 patients with impaired glucose tolerance without a significant change in mean insulin concentrations. Thus the authors conclude that octreotide improves both glucose metabolism and insulin sensitivity by an increased ability of insulin to suppress hepatic glucose production; however the peripheral glucose uptake was not affected by treatment. A positive experience has been reported by Colao et al. (61). They reported the normalization of blood glucose levels in 3 out of 7 acromegalic patients affected by diabetes and in 2 patients insulin has been replaced by oral hypoglycemic agents, and in other 2 patients insulin dosage was reduced. The improvement in glucose metabolism was associated with a significant reduction in serum $\mathrm{GH}$ and IGF-I levels. However octreotide is not always capable to ameliorating carbohydrate metabolism; there are some reports showing that it deteriorates glucose tolerance in patients with acromegaly. The International Multicenter Acromegaly Study Group (62) evaluated the clinical and biochemical effects of long-term therapy with octreotide and reported a worsening of glucose tolerance in $48 \%$ of 25 assessed patients. In 2 out of 25 acromegalic patients there was an ameliorating carbohydrate metabolism. Another study (63) investigated the effects of the SA on glucose tolerance in 90 acromegalic patients. At baseline 11 patients were diabetic, 24 had an impaired glucose tolerance and 55 had normal glucose tolerance. During octreotide therapy about $20 \%$ of patients who had normal carbohydrate metabolism have developed impaired glucose tolerance and $29 \%$ became frankly diabetic; 3 of 11 patients who were diabetic at baseline became normal $(18 \%)$ or developed impaired glucose tolerance $(9 \%)$. No relationship was observed between the dose of octreotide and the change in glu- 
cose tolerance. Patients with elevated baseline insulin levels were more likely to become diabetic; so this study has showed a significant deterioration in glucose metabolism both in acromegalic patients with normal and impaired glucose tolerance. In the Italian Multicenter Octreotide Study (64) it has been shown that SA treatment is able to deteriorate the glucose tolerance in acromegaly: $25 \%$ of patients with overt diabetes mellitus had an impairment of their metabolic control after treatment with octreotide. The divergent effects of octreotide on glucose tolerance may be explained by the multiple complex effects of this drug on glucose metabolism $(65,66)$. Octreotide may induce an increase in blood glucose concentration by inhibiting insulin secretion from pancreatic beta cells. Moreover it has been reported that this SA increases IGF$\mathrm{BP}-1$ concentration counteracting the insulin-like effect of IGF-I $(67,68)$. On the other hand octreotide may induce a decrease in blood glucose levels by inhibiting GH and IGF-I hypersecretion. The reduction in circulating GH levels can induce an inhibition of gluconeogenesis and an increase of insulin sensitivity with an improved insulin action both at the receptor and post-receptor level. Furthermore octreotide inhibits the secretion of insulin, glucagon and other intestinal hormones, reduces gastrointestinal movements and consequently glucose absorption. These multiple effects of octreotide at different steps involved in glucose metabolism may explain the individual differences and the unpredictable effect of this drug on glucose tolerance in acromegalic patients also if the genetic background of these patients must be taken in consideration. The long-term follow up studies with long-acting SA do not show any impairment of glucose tolerance (69-71). Further studies are necessary to elucidate the effects of these new formulations on glucose tolerance. We have published a paper where twenty-four active acromegalic patients were studied in order to determine the long-term effects of octreotide-LAR and SR-lanreotide on insulin sensitivity and carbohydrate metabolism (27). All patients underwent an oral glucose tolerance test (OGTT) and 12 also had an euglycaemic hyperinsulinaemic clamp and were evaluated at baseline and after 6 months of SA therapy. The results of these paper showed that acromegalic patients had low M-values (insulin sensitivity index) in respect to the control group at baseline, followed by a significant improvement after 6 months of therapy. Moreover serum glucose levels at 120 min during OGTT worsened during SA therapy in patients with normal glucose tolerance, but not in those with impaired glucose tolerance or diabetes mellitus. This was associated with a reduced and 30 min delayed insulin secretion during OGTT. Also, HbA1c significantly deteriorated in all subjects after treatment. It was concluded that in acromegalic patients SA treatment reduces insulin resistance, and also impairs insulin secretion suggesting the use of oral secretagogue hypoglycaemic agents and/or insulin therapy as treatment of choice in acromegalic patients who develop frank hyperglycaemia during somatostatin analogs therapy. More recent evidences reported a similar prevalence of dete- rioration and improvement of glucose tolerance 12 months after first-line SA treatment $(72,73)$, with uncontrolled acromegaly despite SA therapy and abnormal glucose tolerance at baseline being associated with glucose tolerance worsening. A recent study by Giordano $C$ et al. (74) compared the effects of first-line SA or surgery on glucose metabolism in acromegaly. Both treatments have been shown to improve insulin sensitivity and visceral adiposity index (VAI), a new marker of metabolic syndrome. Interestingly, successful treatments able to normalize disease activity and to ameliorate glucose tolerance have been shown to shortly result in the improvement of quality of life in acromegalic patients $(74,75)$.

Dopamine agonists have controversial effects on glucose tolerance, and no significant effect on glucose metabolism has been reported (76).

New perspectives derive from pegvisomant, a pegylated $\mathrm{GH}$ analog that competes with wild-type $\mathrm{GH}$ for $\mathrm{GH}$ receptor binding sites and prevents functional $\mathrm{GH}$ receptor dimerization, by the inhibition of the signal transduction and IGF-I generation (77).

Pegvisomant-induced normalization of serum IGF-I, an accepted marker of GH-dependent disease activity (77), has been reported in approximately $80 \%$ of acromegalic patients proven to be resistant to longterm conventional SA therapy $(78,79)$. Control of acromegaly induced by pegvisomant has been associated with an improvement of glycometabolic profile: several studies (80-85) have demonstrated that pegvisomant induces a significant decrease in fasting glucose until normal levels also in patients with diagnosed diabetes mellitus and impaired glucose tolerance, and improves insulin resistance by the reduction of HOMA-index and the increase of pancreatic $\beta$-cell secretory function (HOMA- $\beta$ ).

Co-administration of pegvisomant and SA showed discordant effects on glucose homeostasis in different series of acromegalic patients (86-88). However, it is a matter of fact that a good control of hyperglycemia can be successfully achieved in the majority of acromegalic patients with overt diabetes or impaired glucose tolerance, independently on the administered treatment to control $\mathrm{GH}$ excess.

Only a study (89) compared the effects of SA and pegvisomant, either as monotherapy or combined treatment, on glucose profile in acromegaly. Fasting plasma glucose levels significantly vary during the study, being highest during SA treatment and lowest levels during pegvisomant therapy: $5.9 \pm 0.3 \mathrm{mmol} / \mathrm{L}$ while on somatostatin analogs, $5.4 \pm 0.4 \mathrm{mmol} / \mathrm{L}$ in active patients after somatostatin analogs discontinuation, $5.0 \pm 0.2 \mathrm{mmol} / \mathrm{L}$ during pegvisomant $10 \mathrm{mg}, 4.7$ \pm 0.2 on pegvisomant $15 \mathrm{mg}$, and $5.3 \pm 0.3$ while on combined treatment $(p=0.02)$.

When both surgical or medical treatment of acromegaly are ineffective in ameliorate the glucose intolerance and insulin resistance it should be necessary to start a specific treatment.

In conclusion, glucose homeostasis disorders occur in at least one third of acromegalic patients. $\mathrm{GH}$ and IGF-I excess lead to insulin resistance by increasing 
basal insulin concentrations and/or affecting receptor expression and post-receptorial mechanisms. Disease control is associated with a significant improvement of insulin resistance and glycometabolic profile, although medical therapy with SA is reported to induce either deterioration or improvement of glucose tolerance, with uncontrolled acromegaly despite SA therapy and abnormal glucose tolerance at baseline being associated with glucose tolerance worsening. Pegvisomant improves insulin resistance and induces a significant decrease in fasting glucose up to normalization in acromegalic patients with diagnosed diabetes mellitus and impaired glucose tolerance. Further studies are still needed to confirm and extend these data.

\section{Acknowledgements}

To the nurses Aurora De Leo and Maristella Mereu for their assistance during the management and treatment of acromegalic patients.

\section{References}

1. Melmed S. Medical progress: Acromegaly. N Engl J Med 2006 Dec 14; 355(24):2558-2573.

2. Colao A, Ferone D, Marzullo P, Lombardi G. Systemic complications of acromegaly: epidemiology, pathogenesis, and management. Endocr Rev 2004 Feb; 25(1):102-152.

3. Foss MC, Saad JA, Paccola GM, Paula JA, Piccinato CE, Moreira AC. 1991 Peripheral Glucose Metabolism in Acromegaly. J Clin Endocrinol Metab 72 (5):1048.

4. Hansen I, Tsalikian E, Beaufrere B., Gerich J, Haymond M. and Rizza R. 1986 Insulin resistance in acromegaly: defects in both hepatic and extrahepatic insulin action. Am I Physiol 250:269.

5. Jap TS, Ho LT. 1990 Insulin secretion and sensitivity in acromegaly. Clin Physiol Biochem 8:64-69.

6. Giustina A, Barkan A, Casanueva FF, Cavagnini F, Frohman L, Ho K, Veldhuis J, Wass J, Von Werder K, Melmed S. Criteria for cure of acromegaly: a consensus statement. J Clin Endocrinol Metab 2000 Feb; 85(2):526-529.

7. Buchfelder M and Schlaffed S. Surgical treatment of pituitary tumors. Best Pract Res Clin Endocrinol Metab 2009, 23:677-692.

8. Ahmed S, Elsheikh M, Stratton IM, Page RC, Adams $\mathrm{CB}$, Wass JA. Outcome of transphenoidal surgery for acromegaly and its relationship to surgical experience. Clin Endocrinol (Oxf) 1999; 50:561-567.

9. Jenkins PJ, Bates P, Carson MN, Stewart PM, Wass JA. Conventional pituitary irradiation is effective in lowering serum growth hormone and insuline -like growth factor-I in patients with acromegaly. J Clin Endocrinol Metab 2006; 91:1239-1245.

10. Minniti G, Traish D, Ashley S, Gonsalves A, Brada M. Risk of second brain tumor after conservative surgery and radiotherapy for pituitary adenoma: update after an additional 10 years. J Clin Endocrinol Metab 2005;
90:800-804.

11. van der Lely AJ, de Herder WW, Lamberts SW. The role of radiotherapy in acromegaly. J Clin Endocrinol Metab 1997; 82:3185-3186.

12. Abs R, Verhelst J, Maiter D, et al. Cabergoline in the treatment of acromegaly: a study in 64 patients. J Clin Endocrinol Metab 1998; 83:374-378.

13. Sandret L, Maison P, Chanson P. Place of cabergoline in acromegaly: a meta-analysis. J Clin Endocrinol Metab. 2011 May; 96(5):1327-1335.

14. Colao A, Auriemma RS, Lombardi G, Pivonello R. Resistance to somatostatin analogs in acromegaly. Endocr Rev. 2011 Apr; 32(2):247-271.

15. Nikkila EA, Pelkonen R. Serum lipids in acromegaly. Metabolism 1975 Jul; 24(7):829-838.

16. Bates AS, vant'Hoff W, Jones JM, Clayton R. An audit of outcome of treatment in acromegaly. Quarter $\mathrm{J}$ Med 1993; 86:293-299.

17. Holdaway IM, Bolland MJ, Gamble GD. A metaanalysis of the effect of lowering serum levels of $\mathrm{GH}$ and IGF-I on mortality in acromegaly. Eur $\mathrm{J}$ Endocrinol 2008 Aug; 159(2):89-95.

18. Rizza R, Go V, Cryer P, Verdonk C, Gerich J. Stimulation of human pancreatic polypeptide secretion by hypoglycemia is independent of adrenergic mechanisms. J Clin Endocrinol Metab 1982 Dec; 55(6):1234-6.

19. Lawrence JH, Tobias CA, Linfodt JA, Barnn J, Lyman T, Chang CY, Manaugian E, Wei WC. 1970 Successfull treatment of acromegaly: metabolic and clinical studies in 145 patients. J Clin Endocrinol Metab 31:180-188.

20. Colao A, Merola B, Ferone D, Lombardi G. 1997 Acromegaly. J Clin Endocrinol Metab. 82:2777-2781.

21. Beck P, Schalch D, Parker M, Kipnis D, Daughaday W. Correlation studies of growth hormone and insulin plasma concentrations with metabolic abnormalities in acromegaly. J Lab Clin Med 1965; 66:366-379.

22. Mori K, Iwasaki Y, Kawasaki-Ogita Y, Honjo S, Hamamoto Y, Tatsuoka H, Fujimoto K, Ikeda H, Wada Y, Takahashi Y, Takahashi J, Koshiyama H. Improvement of Insulin Resistance Following Transsphenoidal Surgery in Patients with Acromegaly: Correlation with Serum IGF-1 Levels. J Endocrinol Invest 2013 May 10.

23. Clayton R, Vrionides $\mathrm{Y}$, Lynch S, Butt W, London D. Responses of acromegaly to long-term bromocriptine therapy: a biochemical and clinical assessment. Acta Endocrinol 1978; 89:469-482.

24. Fineberg S, Merimee T. Acute metabolic effects of human growth hormone. Diabetes 1974; 23:499-504.

25. Rolefsema F, Goslings B, Frolich M, Moolenaar A, VanSeters A, VanSlooten $\mathrm{H}$. The influence of bromocriptine on serum levels of growth hormone and other pituitary hormones and its metabolic effects in active acromegaly. Clin Endocrinol 1979; 11:235244.

26. Drake WM, Rowles SV, Roberts ME, Fode FK, Besser GM, Monson JP, Trainer PJ. Insulin sensitivity and glucose tolerance improve in patients with acromegaly converted from depot octreotide to pegvisomant. Eur J Endocrinol 2003 Dec; 149(6):521-7. 
27. Baldelli R, Battista C, Leonetti F, Ghiggi MR, Ribaudo MC, Paoloni A, D'Amico E, Ferretti E, Baratta R, Liuzzi A, Trischitta V, Tamburrano G. Glucose homeostasis in acromegaly: effects of long-acting somatostatin analogues treatment. Clin Endocrinol (Oxf) 2003 Oct; 59(4):492-499.

28. Biering H, Knappe G, Gerl H, Lochs H. Prevalence of diabetes in acromegaly and Cushing syndrome. Acta Med Austriaca 2000; 27(1):27-31.

29. Kasayama S, Otsuki M, Takagi M, Saito H, Sumitani S, Kouhara H, Koga M, Saitoh Y, Ohnishi T, Arita N. Impaired beta-cell function in the presence of reduced insulin sensitivity determines glucose tolerance status in acromegalic patients. Clin Endocrinol (Oxf) 2000 May; 52(5):549-555.

30. Kreze A, Kreze-Spirova E, Mikulecky M. Risk factors for glucose intolerance in active acromegaly. Braz J Med Biol Res 2001 Nov; 34(11):1429-1433.

31. Ikeda T, Terasawa H, Ishimura M, Ochi H, Ohtani I, Fujiyama K, Hoshino T. J Clin Endocrinol Metab 1982 Dec; 55(6):1234-1236.

32. Reaven GM. Role of insulin resistance in human disease. Banting lecture. Diabetes 1988; 37:15951607.

33. De Fronzo RA, Ferranini E. Insulin resistance: a multifaceted syndrome responsible for NIDDM, obesity, hypertension, dyslipidemia, and atherosclerotic cardiovascular disease. Diabetes Care 1991; 14:173194. Dec; 75(6):1459-63.

34. Reaven GM. A syndrome of resistance to insulinstimulated glucose uptake (Syndrome X): definition and implication. Cardiovasc Risk Fact 1993; 3:2-11.

35. Gama R, Teale JD, Wright J, Ferns G, Marks V. Hyperproinsulinaemia in acromegaly: evidence for abnormal pancreatic beta-cell function, Ann Clin Biochem 1997; 34:627-631.

36. Muggeo M, Robert S Bar, Roth J, Kahn R. The Insulin resistance of Acromegaly: Evidence for Two Alterations in the Insulin Receptor on Circulating Monocytes. J Clin Endocrinol Metab 1979; 48:17.

37. Balbis A, Dellacha JM, Calandra RS, Bartke A, Turyn D. Down regulation of masked and unmasked insulin receptors in the liver of transgenic mice expressing bovine growth hormone gene. Life Sci 1992; 51(10):771-778.

38. Balbis A, Bartke A, Turyn D. Overexpression of bovine growth hormone in transgenic mice is associated with changes in hepatic insulin receptors and in their kinase activity. Life Sci 1996; 59(16):13631371.

39. Dominici FP, Cifone D, Bartke A, Turyn D. Alterations in the early steps of the insulin-signaling system in skeletal muscle of GH-transgenic mice. Am J Physiol 1999 Sep; 277 (3 Pt 1):E447-454.

40. Eriksson $\mathrm{H}$, Ridderstrale $\mathrm{M}$, Tornqvist $\mathrm{H}$. Tyrosine phosphorylation of the growth hormone $(\mathrm{GH})$ receptor and Janus tyrosine kinase-2 is involved in the insulin-like actions of GH in primary rat adipocytes. Endocrinology 1995 Nov; 136(11):5093-5101.

41. Thirone AC, Carvalho CR, Brenelli SL, Velloso LA, Saad MJ. Effect of chronic growth hormone treatment on insulin signal transduction in rat tissues. Mol Cell
Endocrinol 1997 Jun 20; 130(1-2):33-42.

42. Thirone AC, Paez-Espinosa EV, Carvalho CR, Saad MJ. Regulation of insulin-stimulated tyrosine phosphorylation of Shc and IRS-1 in the muscle of rats: effect of growth hormone and epinephrine. FEBS Lett. 1998 Jan 16; 421(3):191-196.

43. Myers MG Jr, Sun XJ, White MF. The IRS-1 signaling system. Trends Biochem Sci 1994 Jul; 19(7):289293.

44. Carter-Su C, Schwartz J, Smit LS. Molecular mechanism of growth hormone action. Annu Rev Physiol 1996; 58:187-207.

45. Kopchick JJ, Andry JM. Growth hormone (GH), GH receptor, and signal transduction. Mol Genet Metab 2000 Sep-Oct; 71(1-2):293-314.

46. Souza SC, Frick GP, Yip R, Lobo RB, Tai LR, Goodman HM. Growth hormone stimulates tyrosine phosphorylation of insulin receptor substrate-1. J Biol Chem 1994 Dec 2; 269(48):30085-30088.

47. Ridderstrale M, Degerman E, Tornqvist H. Growth hormone stimulates the tyrosine phosphorylation of the insulin receptor substrate- 1 and its association with phosphatidylinositol 3-kinase in primary adipocytes. J Biol Chem 1995 Feb 24; 270(8):34713474.

48. Argetsinger LS, Hsu GW, Myers MG Jr, Billestrup N, White MF, Carter-Su C. Growth hormone, interferon-gamma, and leukemia inhibitory factor promoted tyrosyl phosphorylation of insulin receptor substrate-1. J Biol Chem 1995 Jun 16; 270(24): 14685-14692.

49. Kilgour E, Gout I, Anderson NG. Requirement for phosphoinositide 3-OH kinase in growth hormone signalling to the mitogen-activated protein kinase and p70s6k pathways. Biochem J 1996 Apr 15; 315 ( Pt 2):517-522.

50. Adams TE, Hansen JA, Starr R, Nicola NA, Hilton DJ, Billestrup N. Growth hormone preferentially induces the rapid, transient expression of SOCS-3, a novel inhibitor of cytokine receptor signaling. J Biol Chem 1998 Jan 16; 273(3):1285-1287.

51. Takeda R, Tatami R, Ueda K, Sagara H, Nakabayashi $\mathrm{H}$, Mabuchi $\mathrm{H}$. The incidence and pathogenesis of hyperlipidaemia in 16 consecutive acromegalic patients. Acta Endocrinol 1982; 100(3):358-362.

52. Tan KCB, Shiu SWM, Janus ED, Lam KS. 1997 LDL subfractions in acromegaly: relation to growth hormone and insulin-like growth factor-I. Atherosclerosis 129:59-65.

53. Twickler TB, Dallinga-Thie GM, Zelissen PM, Koppeschaar HP, Erkelens DW. The atherogenic plasma remnant-like particle cholesterol concentration is increased in the fasting and postprandial state in active acromegalic patients. Clin Endocrinol (Oxf) $2001 \mathrm{Jul} ;$ 55(1):69-75.

54. Maffei P, Sicolo N, Pebani M. 1999 Lipoprtoein (a) in acromegaly. Annals of Internal Medicine 130:537538.

55. Beentjes JA, van Tol A, Sluiter WJ, Dullaart RP. Low plasma lecithin: cholesterol acyltransferase and lipid transfer protein activities in growth hormone deficient and acromegalic men: role in altered high den- 
sity lipoproteins. Atherosclerosis 2000 Dec; 153(2):491-498.

56. Giustina A, Barkan A, Chanson P, Grossman A, Hoffman A, Ghigo E, Casanueva FF, Colao A, Lamberts S, Sheppard M, Melmed M. Guidelines for the treatment of growth hormone excess and growth hormone deficiency in adults. J Endocrinol Invest 2008; 31: 820-838.

57. Nabarro JD. Acromegaly. Clin Endocrinol (Oxf) 1987 Apr; 26(4):481-512.

58. Roelfsema F, Frolich M. Glucose tolerance and plasma immunoreactive insulin levels in acromegalics before and after selective transsphenoidal surgery. Clin Endocrinol (Oxf) 1985 Apr; 22(4):531-537.

59. Barrande G, Pittino-Lungo M, Coste J, Ponvert D, Bertagna X, Luton JP, Bertherat J. Hormonal and metabolic effects of radiotherapy in acromegaly: longterm results in 128 patients followed in a single center. J Clin Endocrinol Metab 2000 Oct; 85(10):37793785.

60. Freda PU. Somatostatin analogs in acromegaly. J Clin Endocrinol Metab 2002 Jul; 87(7):3013-3018.

61. Ho KK, Jenkins AB, Furler SM, Borkman M, Chisholm DJ. Impact of octreotide, a long-acting somatostatin analog, on glucose tolerance and insulin sensitivity in acromegaly. Clin Endocrinol (Oxf) 1992 Mar; 36(3):271-279.

62. Colao A, Baldelli R, Marzullo P, Ferretti E, Ferone D, Gargiulo P, Peretta M, Tamburrano G, Lombardi G, Liuzzi A. Systemic hypertension and impaired glucose tolerance are independently correlated to the severity of the acromegalic cardiomyopathy. J Clin Endocrinol Metab 2000 Jan; 85(1):193-199.

63. Vance ML, Harris AG. 1991 Long term treatment of 189 acromegalic patients with soamtostatin analog octreotide. Arch Intern Med 151:1573-1578.

64. Koop BL, Harris AG, Ezzat S. Effect of octreotide on glucose tolerance in acromegaly. Eur $\mathrm{J}$ Endocrinol 1994 Jun; 130(6):581-586.

65. Arosio M, Macchelli S, Rossi CM, Casati G, Biella O, Faglia G. Effects of treatment with octreotide in acromegalic patients-a multicenter Italian study. Italian Multicenter Octreotide Study Group. Eur J Endocrinol 1995; 133:430-439.

66. Hirose T, Kuroda T, Otsuki M, Takagi M, Yamamoto H, Motomura T, Kurebayashi S, Miyashita Y, Koga M, Arita N, Hayakawa T, Kishimoto T, Kasayama S. A patient with acromegaly who showed remarkable improvement of hyperglycemia after treatment with octreotide. Intern Med 1997 May; 36(5):345-350.

67. Hizuka N. Divergent effects of octreotide on glucose tolerance in patients with acromegaly. Intern Med 1997 May; 36(5):319-320.

68. Lewitt MS, Baxter RC. Insulin-like growth factor-binding protein-1: a role in glucose counterregulation? Mol Cell Endocrinol 1991 Aug; 79(1-3):C147-52.

69. Ezzat S, Ren SG, Braunstein GD, Melmed S. Octreotide stimulates insulin-like growth factor-binding protein-1: a potential pituitary-independent mechanism for drug action. J Clin Endocrinol Metab 1992.

70. Caron P, Morange-Ramos I, Cogne M, Jaquet P. Three years follow-up of acromegalic patients treated with intramuscular slow-release lanreotide. J Clin Endocrinol Metab 1997; 82:18-22.

71. Flogstad AK, Halse J, Bakke S, Lancranjan I, Marbach $P$, Bruns C, Jervell J. Sandostatin LAR in acromegalic patients: long-term treatment. J Clin Endocrinol Metab 1997 Jan; 82(1):23-28.

72. Colao A, Auriemma RS, Galdiero M, Lombardi G, Pivonello R. Effects of initial therapy for five years with somatostatin analogs for acromegaly on growth hormone and insulin-like growth factor-I levels, tumor shrinkage, and cardiovascular disease: a prospective study. J Clin Endocrinol Metab 2009 Oct; 94(10):3746-3756.

73. Colao A, Auriemma RS, Savastano S, Galdiero M, Grasso LF, Lombardi G, Pivonello R. Glucose tolerance and somatostatin analog treatment in acromegaly: a 12-month study. J Clin Endocrinol Metab 2009 Aug; 94(8):2907-2914.

74. Giordano C, Ciresi A, Amato MC, Pivonello R, Auriemma RS, Grasso LF, Galluzzo A, Colao A. Clinical and metabolic effects of first-line treatment with somatostatin analogues or surgery in acromegaly: a retrospective and comparative study. Pituitary 2011 Nov 25.

75. Sardella C, Lombardi M, Rossi G, Cosci C, Brogioni S, Scattina I, Webb SM, Gasperi M, E. Martino, Bogazzi F. Short- and long-term changes of quality of life in patients with acromegaly: results from a prospective study. J Endocrinol Invest 2010;33:20-25.

76. Jaffe CA, Barkan AL. Treatment of acromegaly with dopamine agonists. Endocrinol Metab Clin North Am 1992 Sep; 21(3):713-735.

77. Trainer PJ, Drake WM, Katznelson L, Freda PU, Herman-Bonert V, van der Lely AJ, Dimaraki EV, Stewart $\mathrm{PM}$, Friend KE, Vance ML, Besser GM, Scarlett JA, Thorner MO, Parkinson C, Klibanski A, Powell JS, Barkan AL, Sheppard MC, Malsonado M, Rose DR, Clemmons DR, Johannsson G, Bengtsson BA, Stavrou S, Kleinberg DL, Cook DM, Phillips LS, Bidlingmaier M, Strasburger CJ, Hackett S, Zib K, Bennett WF, Davis RJ. Treatment of acromegaly with the growth hormone-receptor antagonist pegvisomant. N Engl J Med 2000 Apr 20; 342(16):1171-1177.

78. Biermasz NR, Dekker FW, Pereira AM, van Thiel SW, Schutte PJ, van Dulken H, Romijn JA, Roelfsema $F$. Determinants of survival in treated acromegaly in a single center: predictive value of serial insulin-like growth factor I measurements. J Clin Endocrinol Metab 2004; 89:2789-2796.

79. van der Lely AJ, Hutson RK, Trainer PJ, Besser GM, Barkan AL, Katznelson L, Klibanski A, Herman-Bonert V, Melmed S, Vance ML, Freda PU, Stewart PM, Friend KE, Clemmons DR, Johannsson G, Stavrou S, Cook DM, Phillips LS, Strasburger CJ, Hackett S, Zib KA, Davis RJ, Scarlett JA, Thorner MO. Longterm treatment of acromegaly with pegvisomant, a growth hormone receptor antagonist. Lancet 2001; 358:1754-1759.

80. Colao A, Pivonello R, Auriemma RS, De Martino MC, Bidlingmaier M, Briganti F, Tortora F, Burman P, Kourides IA, Strasburger CJ, Lombardi G. Efficacy of 12-months of treatment with the GH receptor antag- 
onist pagvisomant in patients with acromegaly resistant to long-term, high-dose somatostatin analog treatment: effect on IGF-I levels, tumor mass, hypertension and glucose tolerance. European Journal of Endocrinology 2006; 154:467-477.

81. Pivonello R, Galderisi M, Auriemma RS, De Martino MC, Galdiero M, Ciccarelli A, D’Errico A, Kourides I, Barman P, Lombardi G, Colao A. Treatment with growth hormone receptor antagonist in acromegaly: effect on cardiac structure and performance. J Clin Endocrinol Metab 2007; 92(2):476-482.

82. Drake WM, Rowles SV, Roberts ME, Fode FK, Besser GM, Monson JP, Trainer PJ. Insulin sensitivity and glucose tolerance improve in patients with acromegaly converted from depot octreotide to pegvisomant. Eur J Endocrinol 2003; 149:521-527.

83. Barkan AL, Burman P, Clemmons DR, Drake WM, Gagel RF, Harris PE, Trainer PJ, van der Lely AJ, Vance ML. Glucose homeostasis and safety in patients with acromegaly converted from long-acting octreotide to pegvisomant. J Clin Endocrinol Metab 2005; 90(10):5684-5691.

84. Linberg-Larsen R, Moller N, Schmitz O, Nielsen S, Andersen M, Orskov H, Jorgensen JOL. The impact of pegvisomant treatment on substrate metabolism and insulin sensitivity in patients with acromegaly. J Clin Endocrinol Metab 2007; 92(5):1724-1728.

85. Parkinson C, Drake WM, Roberts ME, Meeran K, Besser GM, Trainer PJ. A comparison of the effects of pegvisomant and octreotide on glucose, insulin, gastrin, cholecystokinin, and pancreatic polypeptide responses to oral glucose and a standard mixed meal. J Clin Endocrinol Metab 2002 Apr; 87(4):17971804.

86. De Marinis L, Bianchi A, Fusco A, Cimino V, Mormando M, Tilaro L, Mazziotti G, Pontecorvi A, Giustina A. Long-term effects of the combination of pegvisomant with somatostatin analogs (SSA) on glucose homeostasis in non-diabetic patients with active acromegaly partially resistant to SSA. Pituitary 2007; 10(3):227-232.

87. Madsen M, Poulsen PL, Orskov H, Møller N, Jørgensen JO. Cotreatment with pegvisomant and a somatostatin analog (SA) in SA-responsive acromegalic patients. J Clin Endocrinol Metab 2011 Aug; 96(8):2405-2413.

88. Cambuli VM, Galdiero M, Mastinu M, Pigliaru F, Auriemma RS, Ciresi A, Pivonello R, Amato M, Giordano C, Mariotti S, Colao A, Baroni MG. Glycometabolic control in acromegalic patients with diabetes: a study of the effects of different treatments for growth hormone excess and for hyperglycemia. J Endocrinol Invest 2012 Feb; 35(2):154-159.

89. Jørgensen JO, Feldt-Rasmussen U, Frystyk J, Chen JW, Kristensen LØ, Hagen C, Ørskov H. Cotreatment of acromegaly with a somatostatin analog and a growth hormone receptor antagonist. J Clin Endocrinol Metab 2005 Oct; 90(10):5627-5631. 